\title{
Delaying Anthesis of Staminate Pistachio with Paclobutrazol
}

\author{
Ioannis C. Porlingis' and Demetrios G. Voyiatzis ${ }^{2}$ \\ Laboratory of Biology of Horticulture, Aristotelian University of Thessaloniki, \\ Thessaloniki 54006, Greece
}

Additional index words. Pistacia vera

\begin{abstract}
Anthesis of an important staminate pistachio (Pistacia vera L.) cultivar (B) in Greece was delayed by foliar paclobutrazol (PBZ) sprays applied in June or July the previous season. A September spray was ineffective. The amount of delay depended on dose (50 to $1000 \mathrm{mg} \mathrm{PBZ/liter} \mathrm{applied} \mathrm{to} \mathrm{incipient} \mathrm{runoff).} \mathrm{Using} \mathrm{the} \mathrm{same} \mathrm{total} \mathrm{amount} \mathrm{of}$ chemical, one spray was as effective as two sprays 1 month apart. There were no effects on inflorescence fresh weight, pollen production, and pollen germination. Stem elongation was inhibited strongly, but the number of nodes and flower buds per shoot was reduced only slightly. In Expt. 2, two other staminate cultivars (A and C) responded similarly to cultivar B. Treatment effects appeared only during the treatment year, whereas a soil drench was effective for 2 years. PBZ may be able to synchronize the blooming of staminate and distillate pistachio cultivars and result in good fruit set without artificial pollination. Chemical name used: $B$ [(4-chlorophenyl)methyl] $-\alpha+(1,1$ dimethylethyl)-l $H-1,2,4$-triazolel-ethanol (paclobutrazol).
\end{abstract}

Pistachio is a dioecious species in which protandry is observed frequently (Crane and Iwakiri, 1981). In Greece, most pistachio orchards are interplanted with staminate cultivars that bloom earlier than the pistillate cultivar Aiginis. Usually, bloom periods do not overlap sufficiently to obtain satisfactory pollination and fruit set. Thus, it is necessary to collect and store pollen and artificially pollinate during pistil receptivity.

Previous work showed that applying a foliar spray of various paclobutrazol (PBZ) concentrations to the early blooming staminate cultivar B delayed bloom so that it coincided with that of 'Aiginis' without affecting pollen production and germination capacity. Thus, avoiding artificial pollination was possible, but the procedure needed to be refined (Porlingis and Voyiatzis, 1986). The objective of this study was to 1) determine cultivar response to a low range of PBZ concentrations, 2) evaluate the effects of application time and of one vs. two half-strength sprays in spring, 3) provide a preliminary indication of PBZ efficacy and persistence from a soil drench applied to potted trees, and 4) indicate the degree to which staminate cultivars might vary in their responsiveness to PBZ.

Cultivar B, which is the prevalent pollenizer in many Greek orchards, was used in all experiments. In addition, another early blooming cultivar (A) and a late-blooming cultivar (C, introduced as pollenizer much later than $\mathrm{A}$ or B) were used in Expt. 2. All experiments were conducted in the university farm orchard near Thessaloniki, Greece.

Received for publication 3 Aug. 1992. Accepted for publication 26 Feb. 1993. The cost of publishing this paper was defrayed in part by the payment of page charges. Under postal regulations, this paper therefore must be hereby marked advertisement solely to indicate this fact.

'Professor.

2Assistant Professor.
Experiment 1. Seven branches, each having 200 to 300 flower buds, were selected on each of four 35-year-old trees of the staminate cultivar B. Seven PBZ treatments were applied to each tree, beginning 1) 6 June 1985 , when shoot apical buds had formed and shoot elongation had ceased, but the two apical leaves were still expanding or 2) on 12 July and 26 Sept. 1985. Solutions of PBZ at 0, 50, 100,250 , or $500 \mathrm{mg} \cdot \mathrm{liter}^{-1}$, containing $1 \%$ Actipron (BP Agricultural Branch, London) as a surfactant, were applied on 6 June to individual branches as foliar sprays to incipient runoff using a hand sprayer. One solution of $500 \mathrm{mg} \cdot$ liter ${ }^{-1}$ only was applied on each of the last two dates. The design was a randomized complete block, with four single-branch replications per treatment. Four adjacent nontreated 'Aiginis' trees were used to compare bloom dates.
Experiment 2. The same experimental set up, number of replications, and procedures as in Expt. 1 were followed. Cultivar B tree branches were sprayed once with $\mathrm{PBZ}$ at 0 , 250,500 , or $1000 \mathrm{mg} \cdot \mathrm{liter}^{-1}$ on 28 May 1986 (50 days after anthesis) or twice with 125 or $250 \mathrm{mg}$.liter ${ }^{-1}$.on $28 \mathrm{Apr}$. and 28 May 1986(20 and 50 days after anthesis, respectively). Cultivars $\mathrm{A}$ and $\mathrm{C}$ were treated once with $\mathrm{PBZ}$ at 250 or $100 \mathrm{mg} \cdot$ liter $^{-1}$, respectively, on 28 May 1986. Controls were included.

Experiment. Four-year-old trees growing in 20-liter pots were used. The soil of each of five trees ('B') was drenched with 1 liter of water containing $20 \mathrm{mg}$ PBZ on 10 Sept. 1986. Five similar staminate and five pistillate trees were not treated.

In Expts. 1 and 2, seven to nine shoots on each experimental branch, bearing a total of $\approx 50$ inflorescences, were tagged for bloom date observations. The dates at which $5 \%$ to $10 \%, 45 \%$ to $55 \%$, and $90 \%$ to $95 \%$ of anthers dehisced in the inflorescences of each shoot were recorded. The averages of the first and the last dates were considered the beginning and the end of the bloom period for each shoot, respectively; the bloom period of the branch was taken as the average of those of the tagged shoots. The bloom period of 'Aiginis' was determined on four branches, each on a different tree. The same method was used as with staminate trees, except that the dates at which $5 \%$ to $10 \%$ and $45 \%$ to $55 \%$ of flowers opened and their pistils appeared and $90 \%$ to $95 \%$ of the pistils were brown were recorded. The first and last dates were considered the beginning and the end, respectively, of the bloom period. The bloom period of potted trees was determined based on similar observations taken from all inflorescences ( 30 to 40 ) on each tree.

The effect of PBZ on inflorescence fresh weight, pollen production, and germination capacity in 1986 (Expt. 1) was studied according to methods described by Porlingis and Voyiatzis (1986). The lengths of 15 currentseason's shoots on each experimental branch and the number of nodes and flower buds were

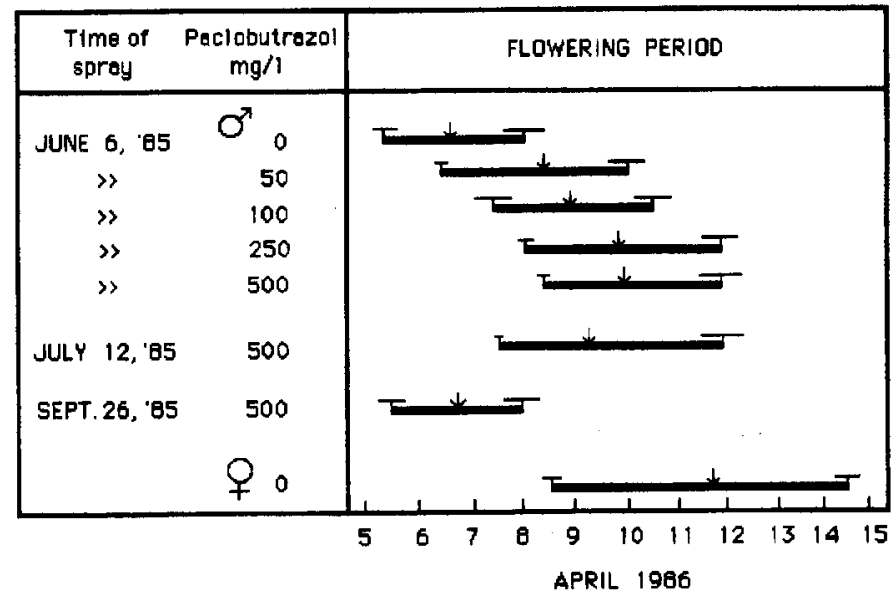

Fig. 1. Bloom periods of the staminate pistachio cultivar B (male), sprayed the previous year with paclobutrazol at several concentrations and dates, compared with that of distillate pistachio cultivar Aiginis. Thin horizontal lines indicate $\pm \mathrm{SE}$ of the mean dates of the beginning and end of each bloom period, and vertical arrows indicate the mean date at which $50 \%$ of the anthers dehisced or $50 \%$ of female flowers opened. 
determined (Expts. 1 and 2). This was done during the treatment year and the following year.

Delayed bloom of cultivar B caused by PBZ the following spring depended on application date and concentration (Fig. 1). A foliar spray in June or July was about as effective. The late-September treatment did not delay anthesis. The bloom period of branches sprayed with PBZ at 250 or $500 \mathrm{mg} \cdot \mathrm{liter}^{-1}$ started at about the same time as that of 'Aiginis' but ended earlier. The same treatments used in Expt. 2 resulted in a complete overlapping of cultivar B and 'Aiginis' bloom periods (Fig. 2) when given as one or two half-strength sprays. PBZ at $1000 \mathrm{mg} \cdot \mathrm{liter}^{-1}$ delayed bloom even

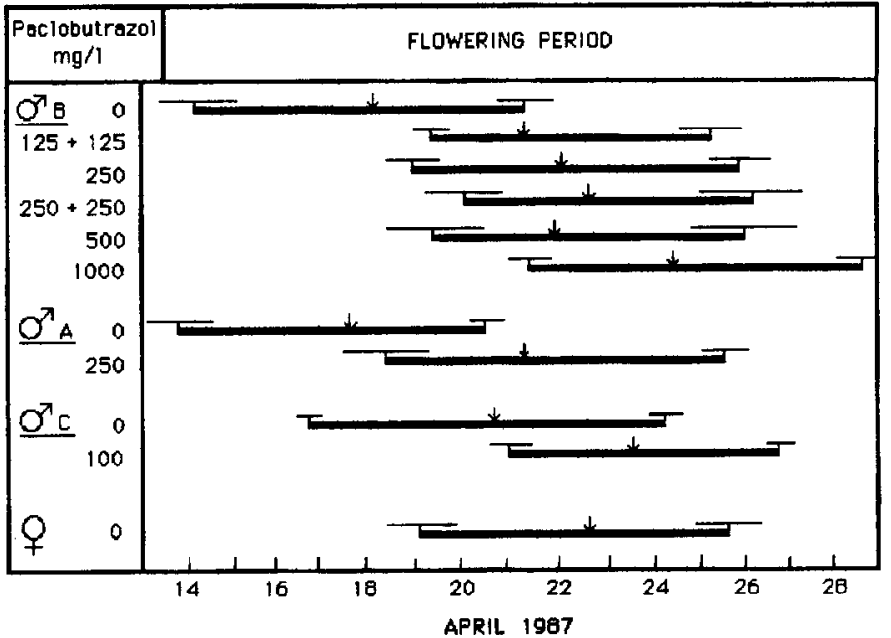

Fig. 2. Bloom periods of staminate pistachio cultivars A, B, and C, sprayed once or twice the previous year (28 May or 28 Apr. and 28 May) with paclobutrazol, compared with that of pistillate pistachio cultivar Aiginis. Thin horizontal lines indicate \pm SE of the mean dates of the beginning and end of each bloom period, and vertical arrows indicate the mean date at which $50 \%$ of the anthers dehisced or $50 \%$ of female flowers opened.

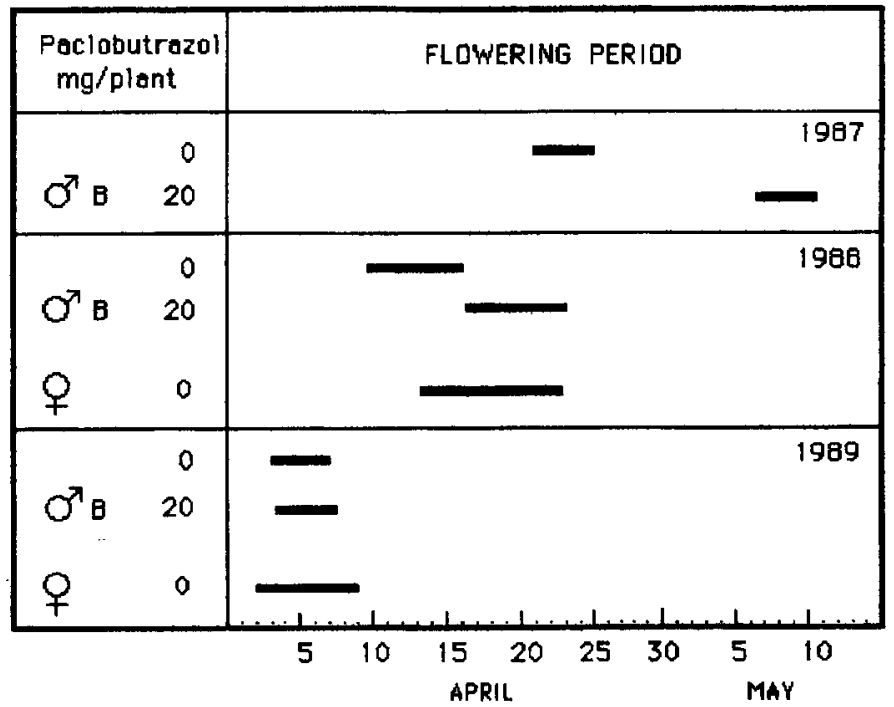

Fig, 3. Bloom periods of potted staminate pistachio cultivar B trees after a soil application of paclobutrazol in Sept. 1986 compared with those of pistillate pistachio cultivar Aiginis in 1987, 1988, and 1989.

Table 1.Effect of foliar paclobutrazol (PBZ) sprays (applied in 1985 on several dates) on staminate pistachio cultivar B annual shoot length, node number, and flower bud number the following year (1986).

\begin{tabular}{lcccc}
\hline $\begin{array}{l}\text { Spray } \\
\text { date }\end{array}$ & $\begin{array}{c}\text { PBZ } \\
\left(\text { mg.liter }^{-1}\right)\end{array}$ & $\begin{array}{c}\text { Annual shoot } \\
\text { growth }(\mathrm{cm})\end{array}$ & $\begin{array}{c}\text { Nodes/ } \\
\text { shoot (no.) }\end{array}$ & $\begin{array}{c}\text { Flower buds/ } \\
\text { shoot (no.) }\end{array}$ \\
\hline 6 June & 0 & $15.7 \mathrm{a}^{2}$ & $9.6 \mathrm{a}$ & $8.8 \mathrm{a}$ \\
& 50 & $3.7 \mathrm{~b}$ & $8.8 \mathrm{ab}$ & $8.2 \mathrm{ab}$ \\
& 100 & $3.0 \mathrm{~b}$ & $7.8 \mathrm{~b}$ & $7.3 \mathrm{~b}$ \\
& 250 & $3.6 \mathrm{~b}$ & $8.5 \mathrm{ab}$ & $7.7 \mathrm{~b}$ \\
12 July & 500 & $2.1 \mathrm{~b}$ & $7.9 \mathrm{~b}$ & $7.2 \mathrm{~b}$ \\
26 Sept. & 500 & $4.1 \mathrm{~b}$ & $8.2 \mathrm{~b}$ & $7.3 \mathrm{~b}$ \\
\hline
\end{tabular}

${ }^{2}$ Mean separation in columns by Duncan's multiple range test $(P \leq 0.05)$. Means did not differ significantly in 1987. more effectively. The bloom period of PBZtreated branches was more prolonged than that of the control in Expt. 1. This extension may have been due to the lower temperature (20 vs. 25C) observed later in the bloom period of treated branches (data not presented). Cultivars $\mathrm{A}$ and $\mathrm{C}$ also responded to $\mathrm{PBZ}$ sprays (Fig. 2). There was no carryover effect of PBZ the second year (data not presented).

A soil drench with $20 \mathrm{mg}$ PBZ/potted tree effectively delayed bloom of cultivar B compared with the control (Fig. 3). The effect persisted through the second year after PBZ application, although the delay was less. Further work is required to evaluate soil application effects on delaying anthesis.

Although bloom time was influenced by PBZ in Expt. 1, inflorescence weight $(\approx 4 \mathrm{~g})$, pollen production $(\approx 83 \mathrm{mg} / \mathrm{g}$ fresh weight per inflorescence), and pollen germination capacity $(\approx 48 \%)$ were not affected by PBZ at 500 $\mathrm{mg} \cdot \mathrm{liter}^{-1}$. PBZ applied in June and July 1985 retarded the growth and opening of vegetative buds the following spring (data not shown) and strongly inhibited stem growth, even with a concentration as low as $50 \mathrm{mg} \cdot \mathrm{liter}^{-1}$, but only a small decrease in node and flower bud number was observed in 1986 (Table 1). The 1985 treatments did not affect growth in 1987, when shoots grew 13 to $18 \mathrm{~cm}$ and there were nine to ten nodes per shoot and seven to nine flower buds per shoot. The lack of response to the September treatment may be attributed to the stem maturation, which inhibited PBZ absorption. Lever (1986) reported that PBZ penetrates mature bark tissues only through lenticels.

In various fruit species or cultivars, PBZ advances (Looney and McKellar, 1987; Marini, 1987; Proebsting and Mills, 1985; Webster et al., 1986) or delays (Curry, 1988; Erez, 1986; Porlingis and Voyiatzis, 1986; Spiers, 1988) anthesis. In cider apple (Malus domestica Borkh.), PBZ advances or delays anthesis depending on the application method (Stinchcombe et al., 1984). However, in all cases, it inhibits vegetative growth. As found for shoot elongation (Davis et al., 1988), there is evidence that PBZ controls bloom time by lowering endogenous gibberellin levels. In peach [Prunus persica (L.) Batsch] and apricot (Prunus armeniaca L.), bloom is advanced (Proebsting and Mills, 1985) or delayed (Bowenand Denckson, 1978; Soni and Yousif, 1978) depending on treatment with PBZ or gibberillic acid, respectively.

The results of these and previous experiments (Porlingis and Voyiatzis, 1986) obtained in three seasons with different anthesis times indicate that PBZ can be used to improve synchrony of bloom periods of protandrous staminate and pistillate pistachio cultivars. A single foliar spray late in spring or early in summer to staminate trees will delay bloom the following year. The optimum concentration depends on the staminate cultivar and the year, but spraying individual branches on each tree with one of a range of suitable PBZ concentrations and leaving other branches unsprayed may ensure an extended and a more complete pollination period for pistillate flow- 
ers. Since pistachio is dioecious, this particular method results in no PBZ residues in the fruit.

Using PBZ maybe an alternative to artificial pollination, until effective pollination is possible by replacing early with late-blooming staminate cultivars.

\section{Literature Cited}

Bowen, H.H. and G.W. Derickson. 1978. Relationship of endogenous flower bud abscisic acid to peach chilling requirements, bloom dates, and applied gibberellic acid. HortScience 13:694-696.

Crane, J.C. and B.T. Iwakhi. 1981. Morphology and reproduction of pistachio. Hort. Rev. 3:376-393.

Curry, E.A. 1988. Chemical control of vegetative growth of deciduous fruit trees with paclobutrazol and RSW04 11. HortScience 23:470-473.
Davis, T. D., G.L. Steffens, and N. Sankhla. 1988. Triazol plant growth regulators. Hort. Rev. 10:63-105.

Erez, A. 1986. Effect of soil-applied paclobutrazol in drip irrigated peach orchards. Acts Hort. 179:513-520.

Lever, B.G. 1986. "Cultar"-A technical overview. Acts Hort. 179:459-466.

Looney, W.E. and J.E. McKellar. 1987. Effect of foliar- and soil surface-applied paclobutrazol on vegetative growth and fruit quality of sweet cherries. J. Amer. Soc. Hort. Sci. 112:7 1-76.

Marini, R.P. 1987. Growth and cropping of 'Redhaven' peach trees following soil applications of paclobutrazol. J. Amer. Soc. Hort. Sci. 112:18-21.

Porlingis, LC. and D.G. Voyiatzis. 1986. Flower synchronization of staminate and pistillate pistachio trees (Pistacia vera L.) with paclobutrazol. Acts Hort. 179:521-527.
Proebsting, E.L. and H.H. Mills. 1985. Cold resistance in peach, apricot, and cherry as influenced by soil-applied paclobutrazol. HortScience 20:88-90.

Soni, S.L. and Y.H. Yousif. 1978. Inducing delay in the flowering of apricot with growth regulators. Indian J. Agr. Sci. 48:197-200.

Spiers, J.M. 1988. Response of 'Tifblue' rabbiteye blueberry to soil-applied paclobutrazol. HortScience 25:837-839.

Stinchcombe, G.R., E. Copas, R.R. Williams, and G. Arnold. 1984. The effect of paclobutrazol and daminozide on the growth and yield of cider apple trees. J. Hort. Sci. 59:323-327.

Webster, A. D., J.D. Quinlan, and P.J. Richardson. 1986. The influence of paclobutrazol on the growth and cropping of sweet cherry cultivars. I. The effect of annual soil treatment on the growth and cropping of Cv. Early Rivers. J. Hort. Sci. 61:471-478 